\title{
Warren Dean e a premissa irresponsável da máxima lucratividade
}

\author{
Guilherme Pinheiro Furusawa. \\ DEAN, Warren K. A Ferro e Fogo: a história e a devastação da Mata Atlântica brasileira. São Paulo: \\ Companhia das Letras, 1996.
}

Warren Kempton Dean (1932-1994) foi um historiador estadunidense que desenvolveu cuidadosos estudos acerca da sociedade brasileira, por isso, categorizado como um brasilianista por inúmeros autores no campo da historiografia. Foi autor de algumas obras que, por sua profundidade e qualidade, logo se tornaram referências obrigatórias. Entre elas, estão A industrialização de São Paulo (São Paulo, Difel, 1971), Rio Claro: um sistema brasileiro de grande lavoura, 1820-1920 (Rio de Janeiro,Paz e Terra, 1977), A luta pela borracha no Brasil (São Paulo, Nobel, 1989) e A Ferro e Fogo: a história e a devastação da Mata Atlântica brasileira (São Paulo, Companhia das Letras, 1996). Warren Dean faleceu pouco depois de concluir esta última obra, publicada postumamente. A obra representou um grande marco na consolidação da história ambiental como campo de estudo no Brasil. É sobre ela, que tecemos algumas breves considerações.

Pesquisando em fontes de diversas naturezas, derramando conhecimentos em Biogeografia, Paleontologia, Antropologia, Geografia, Ecologia, Botânica e naturalmente História do Brasil, W. Dean demonstra que a nossa história foi marcada por uma grande tragédia vivida pela Mata Atlântica e seus habitantes. Com sua obra, W. Dean ajudou a consolidar a chamada História Ambiental, como campo de estudos no Brasil.

W. Dean tinha como enorme desafio a busca por tecer uma história da Mata Atlântica, que é, ainda hoje, um dos biomas mais ameaçados do Brasil. Sua aventura foi iniciada por uma concisa descrição da formação deste ecossistema há cerca de 80 milhões de anos. A partir deste ponto, seu esforço está em apresentar uma narrativa sobre os dez mil anos de ocupação humana da floresta.

Em sua perspectiva histórica, passa pela forma como os nativos brasileiros se relacionavam com esse bioma, sem a clássica visão romântica sobre o assunto. Neste interim destaca algumas estratégias de caça, bem como a prática da coivara como força motora de enorme transformação do bioma, sem, contudo, colocar-lhe em risco de desaparecimento. Segundo Dean, apesar do forte choque sofrido pelas florestas devido a prática das queimadas, o tipo de interação entre os nativos brasileiros e a natureza, garantiram a este ecossistema enormes possibilidades de auto recuperação. Para isso pesavam uma lógica não destinada à produção e reprodução das queimadas em larga escala (apesar de muitas vezes tais práticas atingirem proporções colossais), com vistas a mercados complexos e alhures, mas apenas destinados aos meios de existência de determinados grupos, sem a produção em larga escala para o abastecimento de populações distantes. Assim, a prática da coivara apesar de sua capacidade destruidora, era combinada com uma série de situações, como os deslocamentos populacionais, que permitiram o reestabelecimento daquele complexo ecossistema, sem ameaçar de extinção enormes quantidades de espécies animais ou vegetais.

Contudo, nos últimos 500 anos de história da relação entre o homem e a floresta (período que marca aquilo que ele denomina como de ação dos invasores europeus e seus desdobramentos socioculturais), tal lógica foi drasticamente e dramaticamente alterada.Vale um destaque para sua observação da estudada "primeira missa", presente em todos os ensaios de História dos livros escolares. Tratando o tema, e o autor ressalta que a primeira "empreitada" pelos portugueses teria sido a derrubada de árvores para a construção da cruz que adornou a primeira missa realizada no Brasil, de acordo com as gravuras que retratam este acontecimento. A instalação dos europeus foi o ponto mais importante em sua retrospectiva histórica, pois trouxeram para a América conceitos de um modo de vida altamente

Professor da Rede Estadual do Rio de Janeiro. Graduado em Ciências Biológicas-Licenciatura pela Universidade Severino Sombra, especializado em Planejamento e Gestão Ambiental pela mesma instituição. Membro colaborador do Instituto Zoobotânico de Morro Azul. Tem experiência na área de Zoologia - Entomologia e Acarologia. 
insustentável do ponto de vista ambiental. A voraz exploração e busca por lucro, para justificar estas viagens altamente dispendiosas fez com que se adotassem aqui medidas que levariam a quase extinção dos recursos que buscavam nesse primeiro momento, como diversas madeiras e enormes glebas de floresta nativa.

É bem verdade que não havia o conhecimento que proporcionasse a compreensão do valor destes recursos preservados. Dessa forma, em contato com uma natureza que parecia inesgotável, os europeus desenvolveram uma cultura predatória e perdulária, buscando o enriquecimento fácil e rápido mediante a exploração indiscriminada destes recursos. Vale ressaltar que, em diversas fontes, observamos que o conceito nutrido pelo colonizador era o de que a terra representava, ou de alguma forma indicava, o grau de desenvolvimento do seu proprietário, ou seja, uma terra "abandonada" ou com alguma cobertura nativa mesmo que com apenas pequenas porções de remanescentes florestais indicavam um proprietário negligente ou desmazelado, enquanto que uma terra descoberta, com benfeitorias, normalmente indicava prosperidade $\mathrm{e}$ segurança.

Suas críticas mais contundentes, nesse momento do livro, se voltam para o sistema de "sesmarias", que promovia o acesso a terra e a devastação florestal com o objetivo do lucro e do suposto desenvolvimento. Essa prática seria ainda a origem das maiores mazelas brasileiras até os dias de hoje, quando se observa a distribuição e o acesso a terra como a mais cruel das problemáticas brasileiras.

Warren Dean fez análise nos diversos Estados que abrigaram alguma relação com este bioma, buscando entender a forma como este bioma foi desaparecendo, com especial atenção às áreas do litoral brasileiro, região onde este bioma se destaca e também da primeira ocupação territorial e, por este motivo, a área mais desenvolvida brasileira. Não se imaginava que pudesse existir desenvolvimento de forma sustentável, com alguma compensação ou harmonia para com os recursos naturais; ou até que estes recursos em algum momento se escasseariam.

Assim, os ciclos da cana de açúcar, borracha, café, as minerações, o surgimento das cidades, ferrovias, rodovias e industrialização, modelos de desenvolvimento, contribuíram para que este bioma chegasse ao século XXI beirando sua extinção, já sendo consideradas extintas diversas espécies nativas e diversas áreas irrecuperáveis.

Por fim, é importante destacar que não desconhecemos algumas das importantes críticas formuladas a obra do autor. Contudo, poderíamos reuni-las em um ponto, qual seja, a que Dean, em sua narrativa teria deixado antever que considerava qualquer intervenção humana como nefasta. Em larga medida, este tipo de entendimento e seus derivantes, estão associados a uma forma de leitura que imprime ao autor um olhar totalizante e incapaz de compreender qualquer ação humana em sinergia com a natureza. Sob esta ótica, a obra, ao tratar uma trajetória mais geral imporia este caminho como a única verdade possível, desconsiderando qualquer possibilidade de interações mais sinérgicas entre homem e natureza, que pudessem ter ocorrência em menor escala.

Sob o nosso ponto de vista, não é bem assim. Entendemos que a obra de Dean é, mais que um tratado de história ambiental, é também um chamamento a uma nova consciência e a um novo tipo de atitude. Neste sentido, a obra não desconsidera a possibilidade de uma nova ordem de ação humana frente aos desafios de preservar os ecossistemas. E neste ponto, certamente a obra de Dean nos chama a urgência da maior capacidade de ampliar os pressupostos sociais no trato humano do homem com o ambiente.

Não acreditamos que o autor desconhecesse ou desconsiderasse os esforços de grupos minoritários na construção de uma nova lógica de relação entre homem e natureza. Contudo, apesar dos esforços de diversos seguimentos da sociedade, ainda hoje não conseguimos alterar a regra geral sob a qual, a maioria das áreas florestadas ainda está em risco exponencial de desaparecimento. No período colonial, no Império, na República civil, no Estado Novo, no autoritarismo militar ou na Nova República não encontramos em nenhum momento, a real preocupação com estes recursos. Ainda hoje, mesmo com o entendimento que já existe, ainda se associam o desenvolvimento com a exploração destes recursos sob a premissa irresponsável da máxima lucratividade.

Quando refletimos acerca da obra magistral do jornalista uruguaio Eduardo Galeano (1940-2015) As veias abertas da América Latina, que propõe uma observação dos 500 anos da história da América Latina buscando retratar suas principais bases: a economia agrícola e mineradora, ambas sempre dominadas/ exploradas pelo mercado internacional, observamos como conseqüência deste quadro histórico a pobreza social como um dos resultados desse sistema econômico excludente, que privilegia uma minoria financeiramente capaz de integrar-se aos padrões de consumo e conivente com esse sistema, promovendo desta forma intensa desigualdade social e, naturalmente intensa destruição dos recursos naturais que são a base dessa exploração e concomitantemente nenhuma preocupação efetiva acerca da relação mais sustentável com a natureza, fonte direta ou indireta destes recursos. Isso talvez se dê pela velocidade com que se intentam os lucros e/ou, quem sabe, pela falsa sensação de inesgotabilidade que essa gigantesca e generosa terra apresentava no Novo Mundo.

Neste milênio que se descortina, começamos a perceber desconfortavelmente um pouco dos 
resultados deste modelo de desenvolvimento adotado, principalmente através da escassez de alguns destes recursos. Maiormente quando se observa a diminuição da oferta de água, ameaçando, mesmo que em princípio de forma desigual, todos os que pululam este solo. $\mathrm{E} \mathrm{W}$. Dean, através de seus 15 capítulos já nos alertava desta possibilidade. 